\title{
Groundwater Dynamic and Its Interrelationship with River Water of Bandung Basin Using Environmental Isotopes $\left({ }^{18} \mathrm{O},{ }^{2} \mathrm{H},{ }^{14} \mathrm{C}\right)$
}

\author{
Satrio ${ }^{1}$, Paston S. ${ }^{1}$, Leong Chung $\mathrm{Sum}^{2} \&$ S. Syafalni ${ }^{2,3}$ \\ ${ }^{1}$ Centre for the Application of Isotope and Radiation Technology, National Nuclear Energy Agency (NNEA), \\ Indonesia \\ ${ }^{2}$ School of Civil Engineering, Engineering Campus, Universiti Sains Malaysia (USM), Malaysia \\ ${ }^{3}$ Civil Engineering Department, BINUS University, Indonesia \\ Correspondence: S. Syafalni, School of Civil Engineering, Universiti Sains Malaysia (USM), Malaysia. Tel: \\ 60-4-599-6291. E-mail: cesyafalni@eng.usm.my
}

Received: September 18, 2012

Accepted: October 22, $2012 \quad$ Online Published: October 27, 2012

doi:10.5539/mas.v6n11p49

URL: http://dx.doi.org/10.5539/mas.v6n11p49

\begin{abstract}
The study of the interrelationship between groundwater and surface water is crucial in groundwater basin research. As an effective tracer in groundwater basin research, environmental isotopes can reveal the interrelationship between river water and groundwater. A research of groundwater and river water alongside river of Bandung area and its surrounding has been carried out. This research was conducted by taking some samples of shallow groundwater, deep groundwater and river water (Citarum, Cikapundung, Cikeruh and Citarik). The objective of this research is to determine groundwater recharge area and to investigate the inter-relationship between groundwater and river water. Based on isotopes $\delta{ }^{2} \mathrm{H}$ vs. $\delta{ }^{18} \mathrm{O}$ results, there were a mixing process at three location of shallow groundwater with river water. However, the result of isotope ${ }^{14} \mathrm{C}$ does not show interrelationship, either by shallow groundwater or river water. From iso-age contour lines, it could be concluded that the dynamic patterns of deep groundwater show movement derived from the North and the South mountain to the North-West direction. The actual velocity in the area was around $0.25-3 \mathrm{~m} / \mathrm{year}$ that can be estimated from iso-ages lines contour.
\end{abstract}

Keywords: groundwater, interrelationship, river water, environmental isotopes

\section{Introduction}

Bandung is the capital of West Java province in Indonesia, and it is the fourth largest city after Jakarta, Surabaya, Medan (Figure 1). Bandung Metropolitan city is located in highland (intermountain land). Bandung basin is the study area situated approximately $768 \mathrm{~m}$ above sea level with a latitude of between $7^{\circ} 19^{\prime}-6^{\circ} 24^{\prime} \mathrm{S}$ and a longitude of between $106^{\circ} 51^{\prime}-107^{\circ} 51^{\prime}$ E. The Bandung basin is divided into three sub-basins i.e. Bandung-Soreang, Lembang, and Batujajar sub-basin which are located at two districts (Bandung city and Bandung regency), part of Cimahi city and Sumedang regency respectively (Djumana, 2004). It has seven main tributaries and is one of the biggest river basins on the island of Java. Through the river basin runs its main river Citarum. The total area is $2,340.88 \mathrm{~km}^{2}$ and is divided into 77 sub-districts. The Bandung groundwater basin has many important characteristics. It is a source of drinking water and it supports agriculture, industries and fisheries. Its water is the main source for three existing reservoirs that have a total volume of 6,147 million $\mathrm{m}^{3}$. The groundwater basin in Bandung Metropolitan covers an area of $1,730 \mathrm{~km}^{2}$. It is bordered in the North by the Lembang fault, in the west by impermeable tertiary rocks, and surface water barriers lies in the south and east. (Wangsaatmaja et al., 2005). The lembang fault is a part of depression chain in West Java which is called the Bandung Zone (Van Bemmelen, 1949 in Delimon, 2009). The Bandung Zone can be regarded as a graben-like longitudinal belt of intramontane depressions, extending through the central part of West Java (Figure 2). In central part of this zone, Bandung Basin and Batujajar sub-basin are located (Delimon, 2009). 


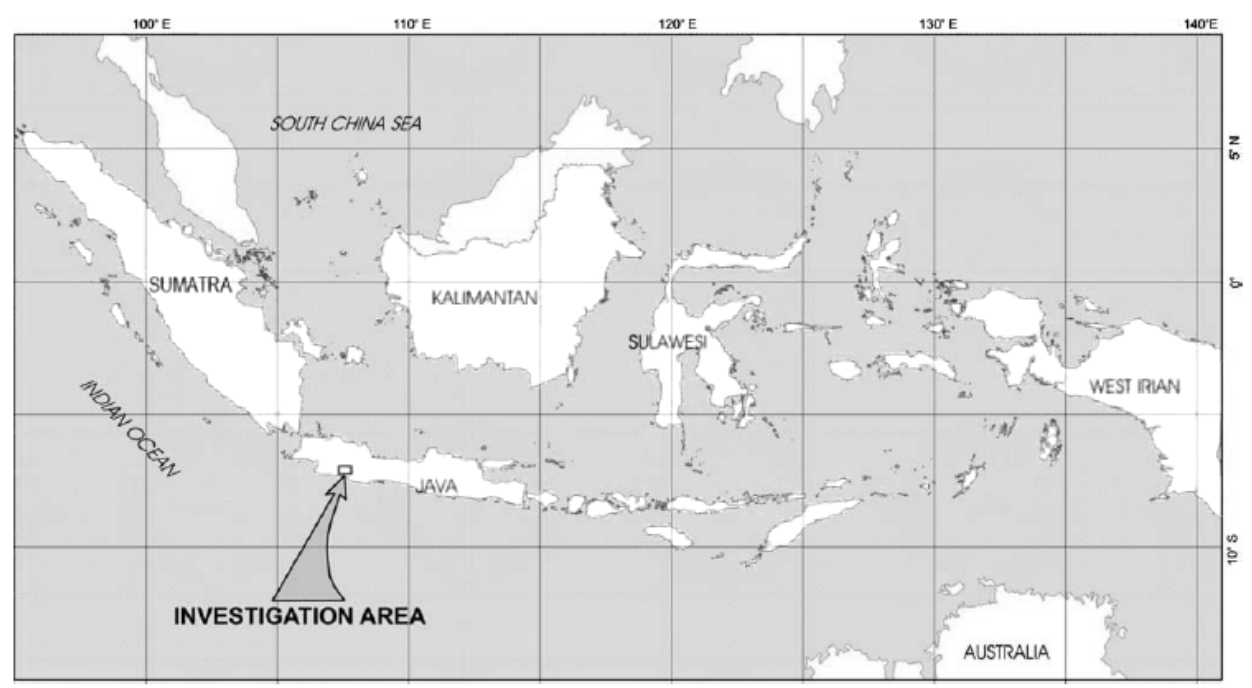

Figure 1. Indonesian map and investigation area (Bandung basin) (after Delimon, 2009)

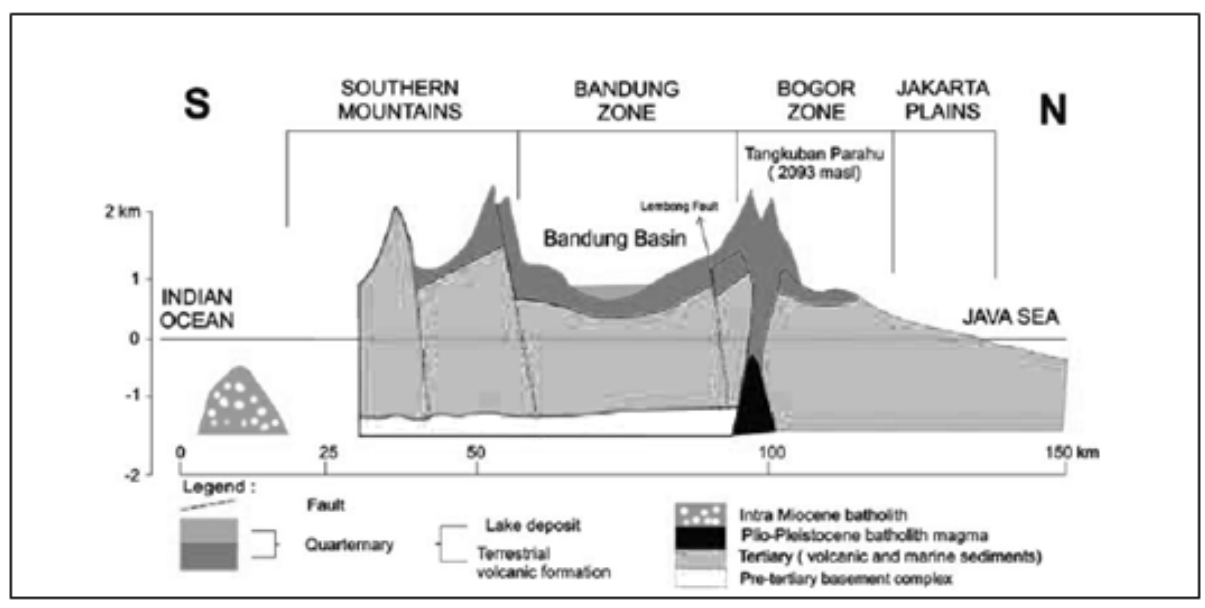

Figure 2. Structural section (N-S) across West Java (after van Bemmelen 1949 in Delimon, 2009)

For 25 years, Bandung Metropolitan has been developed in the industrial and housing sector such as textile, food and drink and there has been a growing demand for water at the area. However, urbanization and industrialization had reduced the recharge, as a significant proportion of the land has become impermeable. The water demand is usually met directly by underground water pumping of varying capacities. According to Yatsuka and Tetsuo (2008), groundwater is easily accessible, cheap and of high quality. Due to its suitability for various purposes, groundwater is used in the course of socio-economic development of modern cities, and is especially used in the early stages of development. Although, groundwater exploitation is not well managed or controlled in many cases and groundwater sources are exploited intensively without consideration for their recharge rate.

The Bandung basin aquifer is heavily exploited for drinking water and other purposes. As a result, the availability of water resources is decreasing and the demand for it is increasing due to increased activities in the area. The major effect of this situation is reflected in the lowering of water table by several meters during the past few years. The water table decreased by $5 \mathrm{~cm}$ to $7.3 \mathrm{~m}$ per year and water level was $100 \mathrm{~m}$ below the ground surface for the year of 2002 (Matahelumual, 2004). Hence, identification of the recharge zone and the directions of movement are very important in the management plan of water resources in Bandung metropolitan. Due to the rapid development of Bandung and its surrounding areas that withdraws water heavily and causes reduction in recharge, the water potential in the area has been reduced. The increasing demands for continuous and extended use of groundwater in these cities along with the lack of effective control have caused a decrease in piezometric level below the water table. The groundwater, shallow groundwater and surface water interaction is complex, with river alternately losing to groundwater or gaining from groundwater along their reaches. Environmental tracers using isotopes are useful for studying the interaction between groundwater and surface water and they 
provide independent means for corroborating or refuting information based on traditional investigations (Baskaran et al., 2009; Ma et al., 2007). Therefore, it is necessary to investigate the movement of groundwater, recharge zone, and the interrelation with the river for understanding Bandung groundwater basin which can be studied by using environmental isotopes such as ${ }^{14} \mathrm{C}, \delta{ }^{18} \mathrm{O}$ and $\delta{ }^{2} \mathrm{H}$.

\section{Hydrogeology}

Geologically, The Bandung basin belongs to the Northern Volcanic Mountain Range which is part of the Bogor zone. This area is surrounded by volcanic complexes including the Tankubanperahu complex in the northern part of the basin which consists of Burangrang Mountain (2076 m above mean sea level (m.s.l)), Tangkubanperahu Mountain (2064 m above m.s.l), Manglayang Mountain (1800 m above m.s.l), and Bukit Jarian Mountain (1282 $\mathrm{m}$ above m.s.l). The Patuha Malabar complex in the southern part of the basin comprises Malang Mountain (1256 m above m.s.l), Cakra Mountain (1807 m above m.s.l), Malabar Mountain (2321m above m.s.l), and Tanjak Nangsi (1514 m above m.s.l). Meanwhile the eastern part of the basin consists of Krenceng (1736 m above m.s.l) and Mandalawangi Montain (1676 m above m.s.l) whereas the western part of the basin comprises Lagadar Mountain, Lalakon Mountain and Padakasih Mountain. Therefore, lithologically quaternary volcanic products with small part of paleo lake deposit built most of this basin. Volcanic products occupy the upper part of the basin while lake deposit is found in the basin basement with a thickness of $100 \mathrm{~m}$. The elevation ranges between 700 and 3,000 m above m.s.l (Matahelumual, 2004). The mean annual rainfall in the Bandung Basin varies from $1000 \mathrm{~mm}$ in mid-regions to the south-east of Bandung city, to more than $3500 \mathrm{~mm}$ in the north and less than $3000 \mathrm{~mm}$ in the south. The wet season extends from November to April. The yearly rainfall intensity ranges between $1700-3500 \mathrm{~mm}$ with a mean value of $2195 \mathrm{~mm} /$ year. The average temperature is $22.6^{\circ} \mathrm{C}$, and its evapotranspiration value is $1,060 \mathrm{~mm} /$ year (Wangsaatmaja et al., 2005).

Puradimaja and Lubis (2006) described that many rivers flowing in Bandung, end at the main river Citarum and pass through different deposit with different hydraulic properties from the North to the South; 3 types of different deposits to be exact found in Cibeureum formation, Cikapundung formation, and Kosambi formation(see Figure 3). All deposites are exposed at the bank (left and right) and bottom of the river where the soil characteristics generally shows high permeability and all segment of Citarum river and its minor stream are effluent. According to Fildebrandt et al. (2003), the general direction of groundwater flow is from the northern and southern mountain ranges towards the Citarum River (see Figure 4). The main source of recharge for the groundwater exploited in the basin occurs in the northern area, based on the evaluation of natural stable isotope concentrations in the groundwater. Delimon (2009) explained that the stable isotope data $\left(\delta^{2} \mathrm{H}\right.$ and $\left.\delta{ }^{18} \mathrm{O}\right)$ of Bandung Basin can be classified into four main groups. Group A from Patuha Malabar complex in the South of Bandung represent deep groundwater which has the lightest isotopic composition. Group B has slightly heavier isotopic composition and is located in the slope area of the northern mountain complex up to the scarp of Lembang Fault. Groups C and D (from the South-East and the East respectively) signify the shallower groundwater flow of local groundwater systems. The differences between these two groups are caused by the type of rainfall and type of vegetation in the surrounding area.

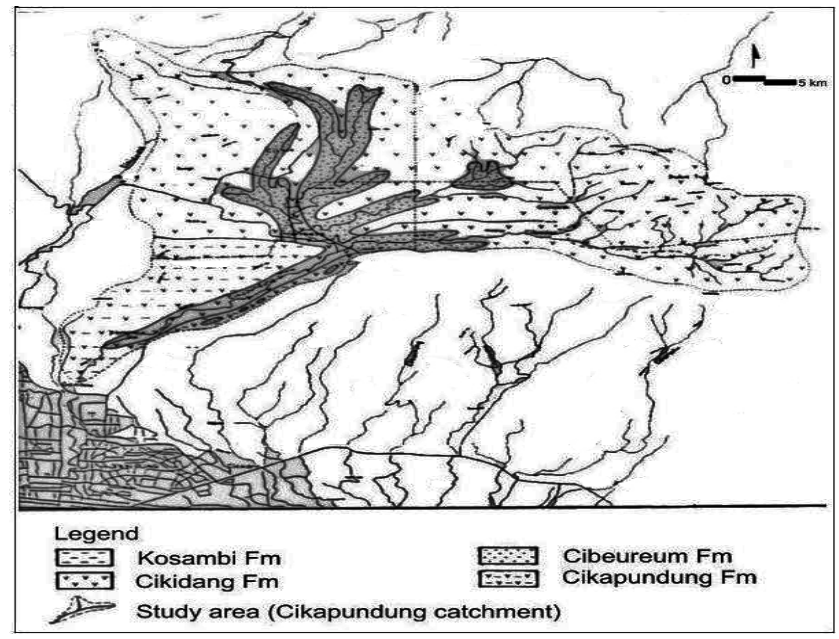

Figure 3. Geology of Cikapundung catchment that relate to Bandung Basin (after Puradimaja \& Lubis, 2006)

Lithological description: (1) Kosambi Fm (lake deposit): unconsolidated sand and clay moderately productive aquifer. (2) Cibereum Fm: volcanic breccia (coarse grain) and volcanic sand with lava intercalation. (3) Cikidang Fm: basaltic lava, impermeable layer. 


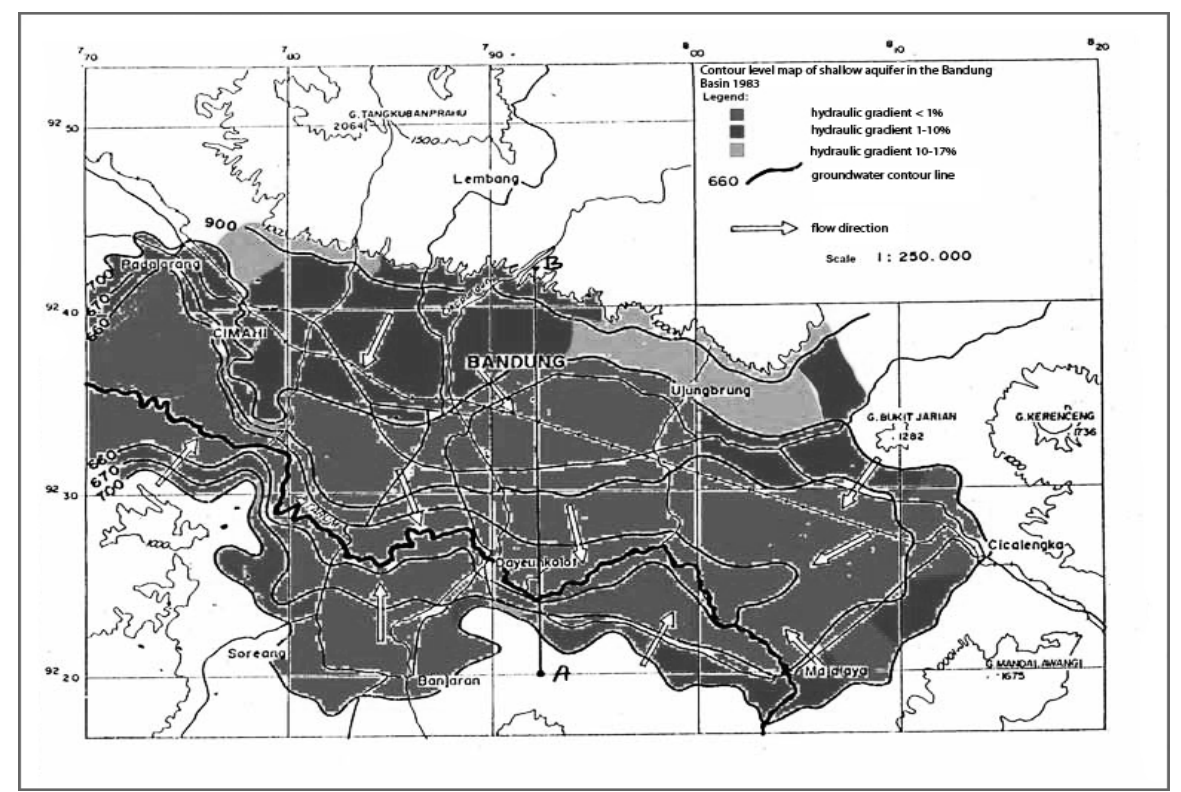

Figure 4. Hydraulic gradients of the shallow aquifer of the Bandung Basin (after Fildebrandt et al., 2003)

In 1990 the groundwater level in the centre of the basin declined from 1-2 m below the ground surface elevation to about $5 \mathrm{~m}$ below the surface whereas in the elevated areas, the groundwater level reduced to about $15 \mathrm{~m}$ below the surface. In 1970 there were 96 deep wells registered, 971 in 1990 and by 1995 it was estimated that there were up to 4700 deep wells existed. In the early 1900's, the piezometric levelswere between 20 and $25 \mathrm{~m}$ above surface, while the piezometric level in the present lies generally more than $50 \mathrm{~m}$ below the surface. The piezometric head has been declining continuously at a rate of between 2-4 m/year, which is altering the groundwater flow system. Vertical downward leakage now occurs within the Bandung area, as the heads in the deep system are now generally lower than in the shallow system (Fildebrant et al., 2003).

\section{Method}

The study area comprises Bandung Metropolitan City. Locations of the sampling points are shown in Figure 5 and Tables 1-2. Twenty four (24) deep groundwater samples were collected in the first set from the existing wells, and 28 samples were collected from shallow groundwater and the river by means of direct pumping (May 2005-September 2006). Stable isotopes $\delta{ }^{2} \mathrm{H}$ and $\delta{ }^{18} \mathrm{O}$ were measured relative to VSMOW (Vienna-Sea Mean Ocean Water) by using Mass Spectrometry model SIRA-9, VG Isogas. The $\delta{ }^{18} \mathrm{O}$ of water was measured by the $\mathrm{CO}_{2}$ equilibration method. For measuring $\delta^{2} \mathrm{H}$, water samples were reduced to hydrogen gas by zinc shots for $\delta^{2} \mathrm{H}$ measurement. The ${ }^{14} \mathrm{C}$ analysis was prepared in the field by adding some chemical solutions such as $\mathrm{NaOH}$ (free $\mathrm{CO}_{2}$ ), $\mathrm{FeSO}_{4} 7 \mathrm{H}_{2} \mathrm{O}, \mathrm{BaCl}_{2}$, and Praestol for faster precipitation for $\mathrm{BaCO}_{3} . \mathrm{BaCO}_{3}$ can be converted to $\mathrm{CO}_{2}$ that will be absorbed by Carbosorb (The reagents can absorb $\mathrm{CO}_{2}$ that can be measured by liquid scintillation counting). The main chemical reactions are as follows (Mook et al., 2001):

$$
\mathrm{BaCO}_{3}+2 \mathrm{HCl} \rightarrow \mathrm{BaCl}_{2}+\mathrm{H}_{2} \mathrm{O}+\mathrm{CO}_{2}
$$

The radioactivity of ${ }^{14} \mathrm{C}$ in Carbosorb is measured by liquid scintillation. Thus, the observed ${ }^{14} \mathrm{C}$ distribution in the Bandung basin is expressed in pMC (percent modern carbon) which will relate to standard (Nair et al., 1995; Qureshi et al., 1995). pMC (percent Modern Carbon) is the residual activity of ${ }^{14} \mathrm{C}$ sample after recalculation with SRM 4990C standard from National Bureau Standard USA. 


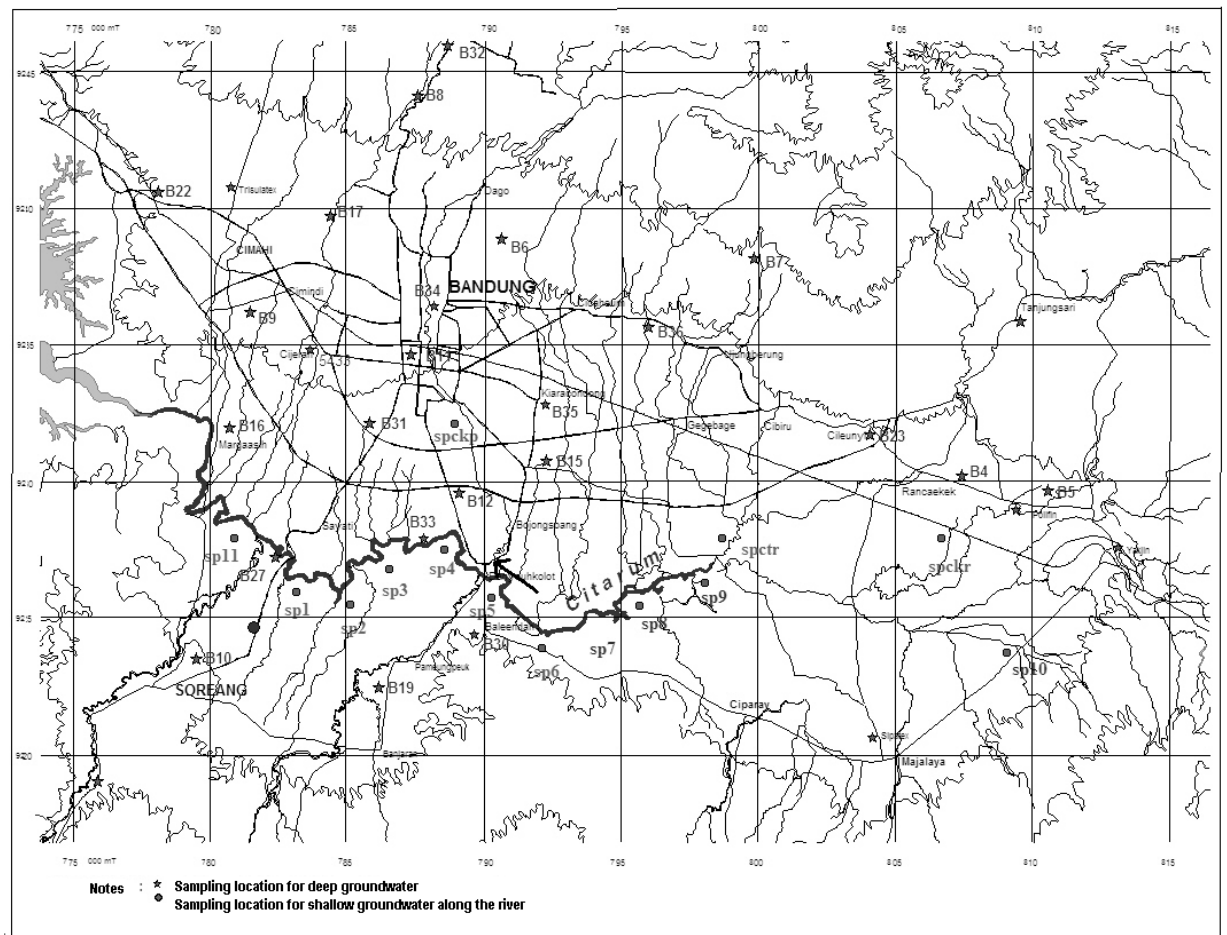

Figure 5. Sampling locations for deep and shallow groundwater along the river

Table 1. Results of $\delta{ }^{18} \mathrm{O}$ and $\delta{ }^{2} \mathrm{H}$ analysis and conductivity of shallow groundwater and river water

\begin{tabular}{|c|c|c|c|c|c|c|c|}
\hline Code & Location & Longitude & Latitude & $\begin{array}{l}\text { Depth } \\
\text { (m) }\end{array}$ & $\begin{array}{l}\delta^{18} \mathrm{O} \\
(\% / 00)\end{array}$ & $\begin{array}{l}\delta^{2} \mathbf{H} \\
(\% / \%)\end{array}$ & $\begin{array}{c}\text { Conductivity } \\
\mu \mathrm{S} / \mathrm{cm}\end{array}$ \\
\hline CTM1 & Kopo & $107^{\circ} 32^{\prime} 23^{\prime \prime}$ & $6^{\circ} 43^{\prime} 12^{\prime \prime}$ & River & -8.40 & -53.2 & 362 \\
\hline SP1 & Kopo & $107^{\circ} 33^{\prime} 30^{\prime \prime}$ & $6^{\circ} 42^{\prime} 57^{\prime \prime}$ & 10 & -8.95 & -55.2 & 445 \\
\hline CTM2 & Ds BjTanjungKatapang & $107^{\circ} 34^{\prime} 20^{\prime \prime}$ & $6^{\circ} 42^{\prime} 59^{\prime \prime}$ & River & -8.84 & -57.3 & 384 \\
\hline SP2 & Ds BjTanjungKatapang & $107^{\circ} 34^{\prime} 30^{\prime \prime}$ & $6^{\circ} 42^{\prime} 42^{\prime \prime}$ & 8 & -8.22 & 53.2 & 497 \\
\hline CTM3 & Ds RancamanyarBlEndah & $107^{\circ} 35^{\prime} 17^{\prime \prime}$ & $6^{\circ} 43^{\prime} 30^{\prime \prime}$ & River & -8.54 & -54.6 & 390 \\
\hline SP3 & Ds RancamanyarBlEndah & $107^{\circ} 35^{\prime} 18^{\prime \prime}$ & $6^{\circ} 43^{\prime} 19^{\prime \prime}$ & 7 & -8.51 & -55.2 & 389 \\
\hline CTM4 & Ds Citepus & $107^{\circ} 36^{\prime} 18^{\prime \prime}$ & $6^{\circ} 43^{\prime} 54^{\prime \prime}$ & River & -8.69 & -55.4 & 459 \\
\hline SP4 & Ds Citepus & $107^{\circ} 36^{\prime} 19^{\prime \prime}$ & $6^{\circ} 43^{\prime} 41^{\prime \prime}$ & 8 & -6.49 & -40.5 & 451 \\
\hline CTM5 & M Toha & $107^{\circ} 37^{\prime} 24^{\prime \prime}$ & $6^{\circ} 42^{\prime} 55^{\prime \prime}$ & River & -7.82 & -47.4 & 535 \\
\hline SP5 & M Toha & $107^{\circ} 37^{\prime} 10^{\prime \prime}$ & $6^{\circ} 42^{\prime} 50^{\prime \prime}$ & 7 & -8.80 & -56.4 & 1188 \\
\hline CTM6 & Ds SindangsariBlEndah & $107^{\circ} 38^{\prime} 15^{\prime \prime}$ & $6^{\circ} 41^{\prime} 59^{\prime \prime}$ & River & -7.97 & -51.2 & 511 \\
\hline SP6 & Ds SindangsariBlEndah & $107^{\circ} 38^{\prime} 13^{\prime \prime}$ & $6^{\circ} 42^{\prime} 35^{\prime \prime}$ & 6 & -8.80 & -56.4 & 682 \\
\hline CTM7 & Ds CiputatBjSoang & $107^{\circ} 39^{\prime} 04^{\prime \prime}$ & $6^{\circ} 42^{\prime} 16^{\prime \prime}$ & River & -6.85 & -38.4 & 447 \\
\hline SP7 & Ds CiputatBjSoang & $107^{\circ} 39^{\prime} 17^{\prime \prime}$ & $6^{\circ} 42^{\prime} 12^{\prime \prime}$ & 33 & -8.57 & -54.5 & 1423 \\
\hline CTM8 & $\begin{array}{l}\text { Ds Bj Mas Solokan jr } \\
\text { Patrol }\end{array}$ & $107^{\circ} 40^{\prime} 02^{\prime \prime}$ & $6^{\circ} 42^{\prime} 57^{\prime \prime}$ & River & -8.81 & -56.5 & 357 \\
\hline SP8 & $\begin{array}{l}\text { Ds Bj Mas Solokan jr } \\
\text { Patrol }\end{array}$ & $107^{\circ} 40^{\prime} 03^{\prime \prime}$ & $6^{\circ} 42^{\prime} 43^{\prime \prime}$ & 4 & -6.34 & -38.6 & 575 \\
\hline СТM9 & Ds LotengSumbersari & $107^{\circ} 41^{\prime} 14^{\prime \prime}$ & $6^{\circ} 43^{\prime} 20^{\prime \prime}$ & River & -8.47 & -53.8 & 486 \\
\hline SP9 & Ds LotengSumbersari & $107^{\circ} 41^{\prime} 20^{\prime \prime}$ & $6^{\circ} 43^{\prime} 07^{\prime \prime}$ & 3 & -7.26 & -44.1 & 573 \\
\hline
\end{tabular}




\begin{tabular}{clllcccc} 
CTM10 & Ds CikawaoPacet & $107^{\circ} 47^{\prime} 03^{\prime \prime}$ & $6^{\circ} 42^{\prime} 04^{\prime \prime}$ & River & -10.0 & -62.4 & 170 \\
SP10 & Ds CikawaoPacet & $107^{\circ} 47^{\prime} 06^{\prime \prime}$ & $6^{\circ} 41^{\prime} 55^{\prime \prime}$ & 6 & -8.53 & -54.2 & 259 \\
CTM11 & Ds GelegongCiharuman & $107^{\circ} 32^{\prime} 31^{\prime \prime}$ & $6^{\circ} 44^{\prime} 09^{\prime \prime}$ & River & -6.54 & -38.3 & 338 \\
SP11 & Ds GelegongCiharuman & $107^{\circ} 32^{\prime} 17^{\prime \prime}$ & $6^{\circ} 43^{\prime} 51^{\prime \prime}$ & 36 & -5.84 & -37.1 & 615 \\
CKR1 & CikeruhJatinangor & $107^{\circ} 46^{\prime} 00^{\prime \prime}$ & $6^{\circ} 43^{\prime} 51^{\prime \prime}$ & River & -7.03 & -42.3 & 164 \\
SPckr1 & CikeruhJatinangor & $107^{\circ} 45^{\prime} 49^{\prime \prime}$ & $6^{\circ} 43^{\prime} 53^{\prime \prime}$ & 2 & -8.69 & -55.5 & 438 \\
CTR & CitarikCicalengka & $107^{\circ} 41^{\prime} 49^{\prime \prime}$ & $6^{\circ} 43^{\prime} 47^{\prime \prime}$ & River & -9.44 & -58.4 & 81 \\
SPctr & CitarikCicalengka & $107^{\circ} 41^{\prime} 41^{\prime \prime}$ & $6^{\circ} 43^{\prime} 53^{\prime \prime}$ & 4 & -9.38 & -59.0 & 192 \\
CKP & Viaduct Cikapundung & $17^{\circ} 36^{\prime} 45^{\prime \prime}$ & $6^{\circ} 45^{\prime} 56^{\prime \prime}$ & River & -7.62 & -46.9 & 263 \\
SPckp & Viaduct Cikapundung & $107^{\circ} 36^{\prime} 17^{\prime \prime}$ & $6^{\circ} 45^{\prime} 50^{\prime \prime}$ & 7 & -7.31 & -44.5 & 396 \\
\hline
\end{tabular}

Tabel 2. Results of ${ }^{14} \mathrm{C}$ analysis and conductivity from Bandung groundwater(depth $>40$ meter)

\begin{tabular}{|c|c|c|c|c|c|c|c|c|c|}
\hline \multirow[b]{2}{*}{ No. } & \multirow[b]{2}{*}{ Code } & \multirow[b]{2}{*}{ Location } & \multirow[b]{2}{*}{ Longitude } & \multicolumn{6}{|c|}{ Cond } \\
\hline & & & & Latitude & $\begin{array}{l}\text { Depth } \\
\text { (m) }\end{array}$ & $\begin{array}{c}\dot{\mu S} / \mathbf{c} \\
\mathbf{m}\end{array}$ & pH & pMC & $\begin{array}{l}\text { Ages } \\
\text { (years) }\end{array}$ \\
\hline 1 & B4 & PT. KahatexCicalengka & $107^{\circ} 46^{\prime} 16^{\prime \prime}$ & $6^{\circ} 44^{\prime} 56^{\prime \prime}$ & 250 & 583 & 7.04 & 80.82 & 1291 \\
\hline 2 & B5 & Coca Cola Rancaekek & $107^{\circ} 47^{\prime} 55^{\prime \prime}$ & $6^{\circ} 44^{\prime} 41^{\prime \prime}$ & 150 & 1972 & 7.00 & 64.74 & 3125 \\
\hline 3 & B6 & STIE WidyatamaCikutra & $107^{\circ} 37^{\prime} 27^{\prime \prime}$ & $6^{\circ} 48^{\prime} 60^{\prime \prime}$ & 150 & 364 & 8.08 & 86.24 & 754 \\
\hline 4 & B7 & $\begin{array}{l}\text { MA Sekehan Panjang Ujung } \\
\text { Berung }\end{array}$ & $107^{\circ} 42^{\prime} 18^{\prime \prime}$ & $6^{\circ} 48^{\prime} 39^{\prime \prime}$ & $\mathrm{S}$ & 217 & 7.70 & 90.94 & 315 \\
\hline 5 & B8 & $\begin{array}{l}\text { Hotel Gumalang Sari } \\
\text { Jl.Setiabudi }\end{array}$ & $107^{\circ} 35^{\prime} 53^{\prime \prime}$ & $6^{\circ} 51^{\prime} 27^{\prime \prime}$ & 120 & 321 & 7.90 & 86.07 & 770 \\
\hline 6 & B9 & PT.Tri Darmatex Lw Gajah & $107^{\circ} 32^{\prime} 37^{\prime \prime}$ & $6^{\circ} 47^{\prime} 42^{\prime \prime}$ & 170 & 479 & 8.05 & 10.22 & 18388 \\
\hline 7 & B10 & Masjid Al FathSoreang & $107^{\circ} 31^{\prime} 31^{\prime \prime}$ & $6^{\circ} 41^{\prime} 46^{\prime \prime}$ & 150 & 399 & 7.64 & 39.35 & 7241 \\
\hline 8 & B11 & Bank BuanaJl.Sudirman & $107^{\circ} 35^{\prime} 45^{\prime \prime}$ & $6^{\circ} 46^{\prime} 59^{\prime \prime}$ & 120 & 428 & 7.82 & 49.98 & 5263 \\
\hline 9 & B12 & PT.BSTM Jl.Moh.Toha & $107^{\circ} 36^{\prime} 37^{\prime \prime}$ & $6^{\circ} 44^{\prime} 39^{\prime \prime}$ & 150 & 601 & 7.55 & 20.58 & 12600 \\
\hline 10 & B15 & PT.LUCAS Ciwastra & $107^{\circ} 38^{\prime} 18^{\prime \prime}$ & $6^{\circ} 45^{\prime} 11^{\prime \prime}$ & 120 & 479 & 8.09 & 53.91 & 4639 \\
\hline 11 & B17 & PT.TrijasaJl.Kol.Supadio & $107^{\circ} 34^{\prime} 13^{\prime \prime}$ & $6^{\circ} 49^{\prime} 23^{\prime \prime}$ & 150 & 424 & 8.28 & 59.67 & 3798 \\
\hline 12 & B19 & PT ProdiaBanjaran & $107^{\circ} 35^{\prime} 21^{\prime \prime}$ & $6^{\circ} 41^{\prime} 16^{\prime \prime}$ & $>40$ & n.a. & n.a. & 81.45 & 1226 \\
\hline 13 & B23 & RumahMakanPonyo & $107^{\circ} 44^{\prime} 31^{\prime \prime}$ & $6^{\circ} 45^{\prime} 37^{\prime \prime}$ & 90 & 416 & 6.50 & 66.56 & 2898 \\
\hline 14 & B22 & PT. WIKA BarosCimahi & $107^{\circ} 30^{\prime} 55^{\prime \prime}$ & $6^{\circ} 49^{\prime} 45^{\prime \prime}$ & $>40$ & n.a. & n.a. & $<0$ & $>35000$ \\
\hline 15 & B27 & PT. Waitex & $107^{\circ} 33^{\prime} 05^{\prime \prime}$ & $6^{\circ} 43^{\prime} 30^{\prime \prime}$ & 180 & 570 & 7.00 & 26.09 & 10639 \\
\hline 16 & B28 & RM CihaliwungCiwidey & $107^{\circ} 29^{\prime} 40^{\prime \prime}$ & $6^{\circ} 39^{\prime} 40^{\prime \prime}$ & $\mathrm{S}$ & 170 & 6.0 & $>100$ & Modern \\
\hline 17 & B29 & Grand Hotel Lembang & $107^{\circ} 35^{\prime} 57^{\prime \prime}$ & $6^{\circ} 52^{\prime} 17^{\prime \prime}$ & 120 & 333 & 6.5 & $>100$ & Modern \\
\hline 18 & $\mathrm{~B} 30$ & PT. DelimatexDayeuhKolot & $107^{\circ} 36^{\prime} 53^{\prime \prime}$ & $6^{\circ} 42^{\prime} 12^{\prime \prime}$ & $>40$ & 412 & 7.32 & 69.97 & 2485 \\
\hline 19 & B31 & Kopo Plaza & $107^{\circ} 34^{\prime} 56^{\prime \prime}$ & $6^{\circ} 45^{\prime} 49^{\prime \prime}$ & $>40$ & n.a. & n.a. & 50.10 & 5248 \\
\hline 20 & B32 & ErdoradoLembang & $107^{\circ} 36^{\prime} 26^{\prime \prime}$ & $6^{\circ} 52^{\prime} 16^{\prime \prime}$ & $>40$ & n.a. & n.a. & $>100$ & Modern \\
\hline 21 & B33 & PT. IntiGunawantex & $107^{\circ} 35^{\prime} 56^{\prime \prime}$ & $6^{\circ} 43^{\prime} 49^{\prime \prime}$ & 150 & n.a. & n.a. & 48.95 & 5438 \\
\hline 22 & B34 & Hotel Grand Hyaat & $107^{\circ} 36^{\prime} 10^{\prime \prime}$ & $6^{\circ} 47^{\prime} 49^{\prime \prime}$ & $>40$ & n.a. & n.a. & 28.18 & 10000 \\
\hline 23 & B35 & PT. Pindad & $107^{\circ} 38^{\prime} 16^{\prime \prime}$ & $6^{\circ} 46^{\prime} 10^{\prime \prime}$ & $>40$ & n.a. & n.a. & 61.50 & 3549 \\
\hline 24 & B36 & PT. BTN Cicaheum & $107^{\circ} 40^{\prime} 17^{\prime \prime}$ & $6^{\circ} 47^{\prime} 30^{\prime \prime}$ & $>40$ & n.a. & n.a. & 60.21 & 3726 \\
\hline
\end{tabular}


The age of groundwater was evaluated using the following formula (Gupta et al., 1985; International Atomic Energy Agency, 1983):

$$
\mathrm{t}=\left(\frac{\mathrm{T}_{1}}{\ln 2}\right) \ln \frac{\mathrm{A}_{0}}{\mathrm{~A}_{\mathrm{t}}}
$$

Where:

$\mathrm{t}=$ ages (in years)

$\mathrm{T}_{1 / 2}=$ Half life for ${ }^{14} \mathrm{C}(5730$ years $)$

$\mathrm{A} 0=$ initial activity

At $=$ activity at time $t$

From ${ }^{14} \mathrm{C}$ analysis, the iso-age line which describes the groundwater dynamic pattern in the study area can be constructed.

For analysis of $\delta{ }^{18} \mathrm{O}$ and $\delta{ }^{2} \mathrm{H}$ in groundwater system, the isotopic composition of groundwater is generally controlled by meteorological processes. According to Clark and Fritz (1997) who explained isotope exchange process by using $\delta{ }^{18} \mathrm{O}-\delta{ }^{2} \mathrm{H}$ diagram, the result is a deviation from meteroric water line along a line with lower slope, which depends on the relative humidity. There exist, however, some extreme geological environments where the reaction between groundwater and the aquifer matrix or subsurface gases can modify the water's meteoric signature. Some typical processes are shown in Figure 6 which explains the water sample for certain location in the study area.

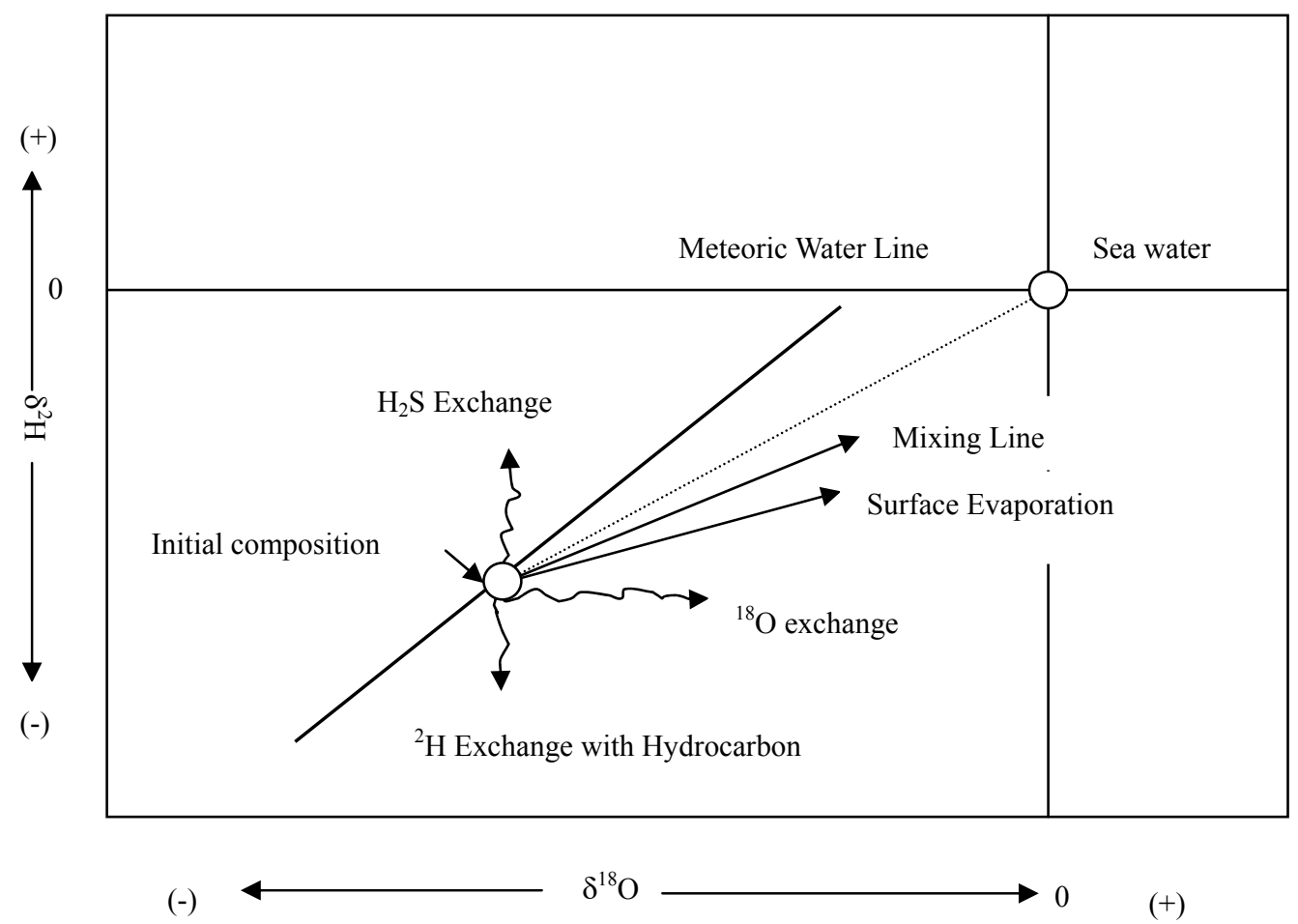

Figure 6. Isotope exchange processes that modify the isotopic composition ofmeteoric water

\section{Result and Discussion}

\subsection{Groundwater Interrelationship}

Many types of industrial activities are taking place in Bandung city, the capital of West Java Province and is located inside the basin. Urbanization has substantially increased the water demand and will increase it even more in the near future. Most factories nowadays use groundwater to fulfill their daily water needs. It is important to know the condition of the existing groundwater and its capacity to utilize the groundwater to its full 
potential. However, intensive use of groundwater results in depletion of the resource that is often associated with other problems such as land subsidence and average drop in water level which were explained previously.

In order to explain Bandung basin characteristics of interaction between river and shallow groundwater, 28 water samples along the Citarum river and shallow groundwater were analyzed for stable isotopic ratio of oxygen and hydrogen while 24 samples of deep groundwater were analyzed for groundwater dating using ${ }^{14} \mathrm{C}$ (see Table 1 and Table 2).

The results for $\delta{ }^{18} \mathrm{O}$ and $\delta{ }^{2} \mathrm{H}$ were expressed in part per thousand (ppt) with a difference in ratio of ${ }^{2} \mathrm{H}$ to ${ }^{1} \mathrm{H}(\delta$ $\left.{ }^{2} \mathrm{H}\right)$ and ${ }^{18} \mathrm{O}$ to ${ }^{16} \mathrm{O}\left(\delta^{18} \mathrm{O}\right)$ in samples relative to Standard Mean Ocean Water (SMOW). The stable isotope of shallow groundwater and river water are displayed in Figure 7. Wandowo et al. (2002) indicated that the relationship between $\delta{ }^{18} \mathrm{O}$ and $\delta{ }^{2} \mathrm{H}$ of Local Meteoric Water Line was $\delta^{2} \mathrm{H}=7.8 \delta^{18} \mathrm{O}+13$. All shallow groundwater sampled water distributes along the line of $\delta^{2} \mathrm{H}=6.73 \delta^{18} \mathrm{O}+3.4$ which indicates surface evaporation occured while river water samples distributes along the line of $\delta^{2} \mathrm{H}=7.37 \delta^{18} \mathrm{O}+9.5$ which is in the range of $\delta$-diagram of precipitation and fall close along the local meteoric origin. The shallow groundwater trend line equation with lower slope explained its origin from surface water from evaporated samples which can be described as interrelated or mixing process in the system (surface water and shallow groundwater). The shallow groundwater and river samples also show that there are three points of shallow groundwater with indication of having contribution from river water. The results showed mixing process between river water and shallow groundwater close to the Cikapundung river (SPCkp), sub-district Loteng Sumbersari (SP9) and sub-district Bojong Mas (SP8), with both wells close to Citarum river, located in the East of Bandung. The distance between shallow groundwater and river is approximately $10 \mathrm{~m}$ to $50 \mathrm{~m}$. The hydrodynamic relationships between groundwater and river water were investigated by Puradimaja and Lubis (2006) for Cikapundung river who identified 3 types of relationship. In the upstream there is no interaction between river and aquifer (type 1), whereas in the middle, the groundwater recharges to the river (type 2) and in the downstream, the river recharge to aquifer (type 3). There is one sample that shows evaporation process for the sub-district Gelonggong Ciharuman (SP11). This sample located at the right of local meteoric water line (LMWL) in the graph, indicates that the water sample come from river or evaporated water. These conditions can be explained using general hydrogeology of Bandung Basin which have been described by Puradimaja and Lubis (2006) that concluded the surface water and groundwater must be managed in integral manner, because surface water body are integral parts of groundwater flow systems.

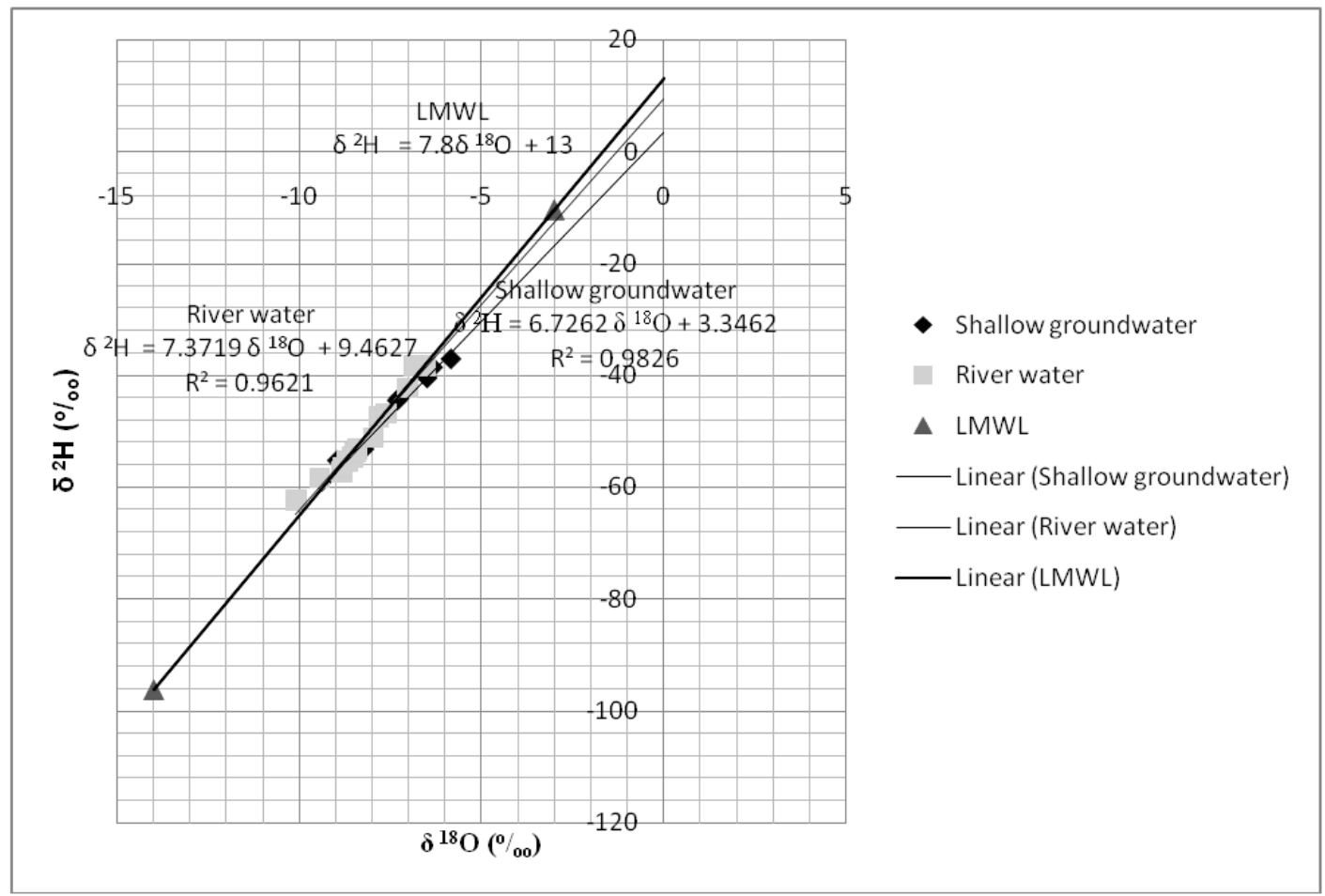

Figure 7. Relationship between $\delta^{18} \mathrm{O}$ and $\delta^{2} \mathrm{H}$ of shallow groundwater and river at Bandung area 


\subsection{Groundwater Quality}

Electrical Conductivity (EC) is the measure of water's ability to conduct electrical current and is closely related to the total dissolved solids (TDS) in the water. Usually measured as $\mu \mathrm{S} / \mathrm{cm}$, conductivity value of water increases with the increase in the amount of dissolved solid in the water. Both tests can be used to monitor the consistency of quality of the groundwater as they indicate the total inorganic mineral content in the water. EC is proportional to TDS with the relation of TDS $=0.64 \mathrm{EC}$, as proved in the findings from the research of hydrogeochemical quality of groundwater in Vedaraniyam Town, TamilNadu, India by Ramkumar et al. (2010).

Based on the conductivity analysis, it is observed that the quality of Citarum river water and shallow groundwater were in the range of fresh water, except for the shallow groundwater from Sub-district. Ciputat Bj. Soang (SP7) indicates that it is near the range of brackish water with conductivity of $1423 \mu \mathrm{S} / \mathrm{cm}$. It is also observed that quality of groundwater was of fresh water, except for Coca Cola Rancaekek which has a conductivity of $1972 \mu \mathrm{S} / \mathrm{cm}$ (B5), as seen in Table 2 for the groundwater with a depth $>40$.

\section{Groundwater Recharge Area}

To explain the movement of groundwater flow in Bandung, 24 water samples within and surrounding the Bandung groundwater basin were analyzed for ${ }^{14} \mathrm{C}$ (percent Modern Carbon), $\mathrm{pH}$, and conductivity, with the depth of groundwater from surface varying from $>40 \mathrm{~m}$ to $250 \mathrm{~m}$ (see Table 2). Based on the results of iso-age lines and hydraulic gradient for shallow groundwater that indicates the depth and flow pattern of groundwater and the shallow groundwater, the general flow direction of Bandung groundwater basin was observed to be from the hill at the North, East and South part of Bandung and gradually move along the Citarum river to the West (see Figure 3 and Figure 8). Hence, it can be said the North, East and South parts are the recharge area for Bandung basin and are considered as conservation area for groundwater of Bandung in which the recharge locations can be clarified by using modern age contour lines. The maximum age for Bandung groundwater was at Leuwigajah (PT. Wika Baros Cimahi) with an age of more than 35000 years. As observed from iso-age contour lines, groundwater movement dynamic pattern tends to move from the North and South to North West (see Figure 8 ) with the actual velocity of about $0.25-3 \mathrm{~m} /$ year, as estimated from the iso-ages line contour plotted from the results of investigation of the piezometric head change of groundwater depth which becomes lower at the North West (Leuwigajah and Cimahi). This area was an industrial area which exploited groundwater resources heavily. Based on the results obtained from land subsidence monitoring in Bandung basin, this condition is caused by an excessive groundwater abstraction (Abidin et al., 2006) which relates to groundwater movement dynamic pattern using iso-age lines. It is also explained that groundwater at deep aquifer is not directly related to shallow aquifer, except for the recharge area that generally hasa young age or modern lines. However, the recharge areas from the North, South, and East of Bandung Basin should be consideredby the Indonesian authority for either groundwater conservation or groundwater injection using basin-well technique. Application of these methods are necessary to solve the problem of intensive groundwater abstraction to fulfill the increasing demand for water and also to avoid land subsidence (Wirakusumah \& Danaryanto, 2004) in suitable location based on iso-age line contour evaluation (Figure 8). 


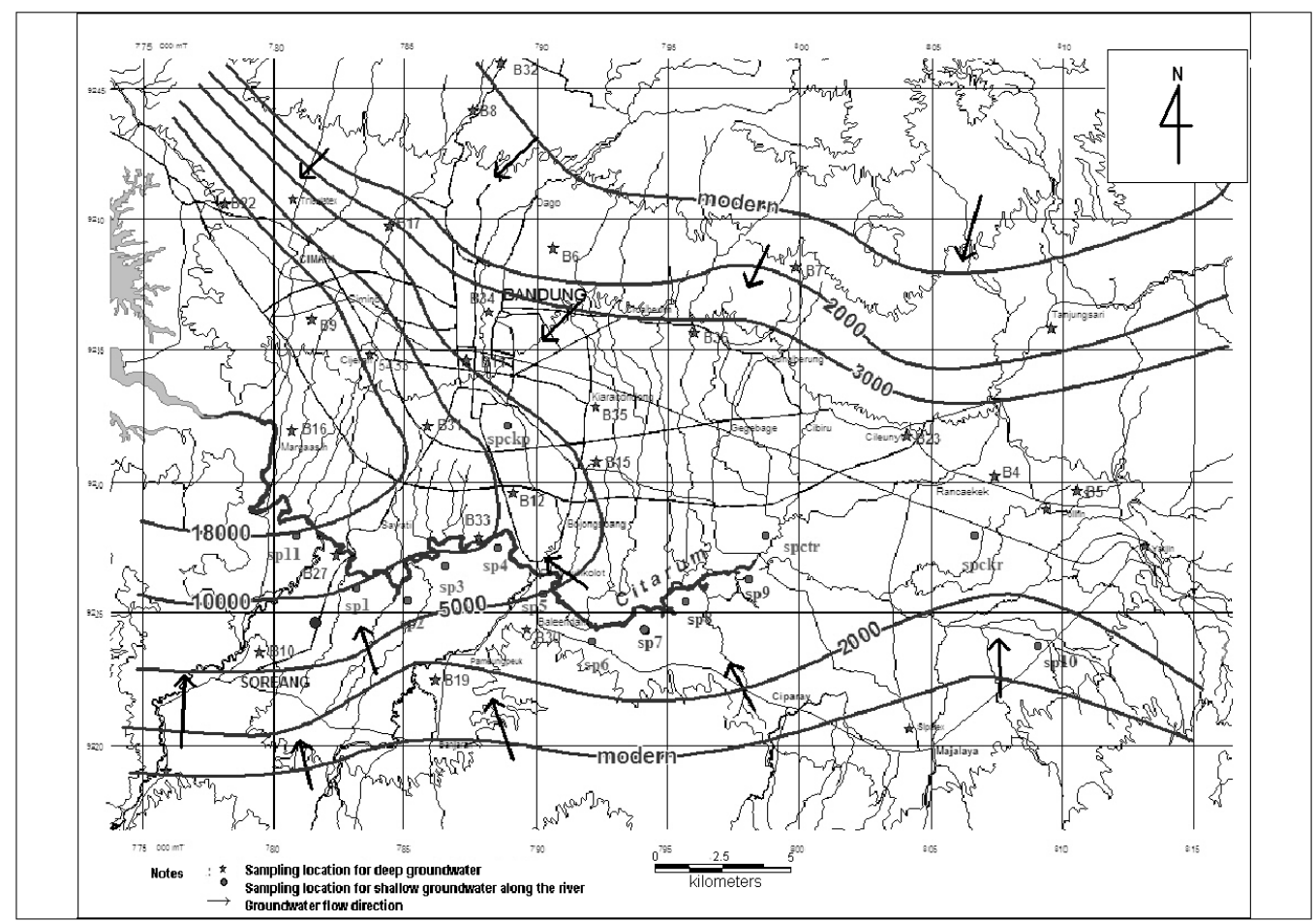

Figure 8. Iso-ages line contour of deep aquifer for Bandung basin

\section{Conclusions}

From the research, it can be concluded that a major part of the shallow groundwater along Citarum river does not relate to the river or deep aquifers and the groundwater originates from the north and south hill with the groundwater with the river water based on the results obtained from environmental isotopes.

The bigest part of shallow groundwater along the Citarum river for Bandung basin does not show interrelationship with river water, except for three sampling point of shallow groundwater that indicates mixing with river water; SPCkp which is close to the Cikapundung river and both Ds Loteng Sumbersari (SP9) and Ds Bojong Mas (SP8) wells which are close to Citarum river.

As observed from the iso-age contour line, the groundwater from deep aquifer does not show interrelationship with shallow groundwater, except at recharge area at the North (Setiabudi-Lembang, Ujung Berung and surrounding) and the South hill side (Rancaekek, Baleendah and surrounding area) which has relatively young water that can be considered as recharge area.

The iso-age contour lines pattern also shows that the origin of groundwater is clearly from the north and south hill with the direction of groundwater flow from the west as proven by using stable isotope (the results of $\delta{ }^{18} \mathrm{O}$ and $\delta{ }^{2} \mathrm{H}$ ). This trend is the result of overexploitation of groundwater by industries around Leuwigajah and Cimahi.

The decision maker should therefore consider groundwater conservation or groundwater injection using basin-well technique to fulfill the demand for water, while maintaining the water level and avoiding land subsidence.

\section{Acknowledgements}

The financial support for the study was provided by Centre for the Application of Isotopes and Radiation Technology, National Nuclear Energy Agency of Indonesia. The authors are indebted to Satriyo Hadipuro from Directorate of Environmental Geology, Department of Mining and Energy, Indonesia for their invaluable data support in completing the research.

\section{References}

Abidin, H. Z., Andreas, H., Gamal, M., \& Darmawan, D. (2006). Land subsidence characteristics of Bandung Basin (Indonesia) between 2000 and 2005 as estimated from GPS surveys. Shaping the Change XXIII FIG Congress (Munich, Germany). 
Baskaran, S., Ransley, T., Brodie, R. S., \& Baker, P. (2009). Investigating groundwater-river interactions using environmental tracers. Australian Journal of Earth Sciences, 56, 13-19. http://dx.doi.org/10.1080/08120090802541887

Clark, I. D., \& Fritz, P. (1997). Environmental isotopes in hydrogeology. New York: Lewis Publishers.

Delimon, R. M. (2009). Structural geology controls on groundwater flow: Lembang Fault case study, West Java, Indonesia. Hydrogeology Journal, 17(4), 1011-1023. http://dx.doi.org/10.1007/s10040-009-0453-z

Djumana. (2004). Cekungan Bandung krisis air, Harian Umum Pikiran Rakyat, Bandung.

Fildebrandt, S., Paul, P., Peter, D., \& Notoatmodjo, P. (2003). Recharge enhancement using single or dual well systems for improved groundwater management in the Bandung Basin, Indonesia. Adelaide: Technical Report, CSIRO Land and Water.

Gupta, Sushil, K., \& Polach, H. (1985). Radiocarbon dating practice at Australian National University. Canberra: Radiocarbon Laboratory, Research School of Pacific Studies, ANU.

International Atomic Energy Agency. (1983). Guidebook on nuclear techniques in hydrology. Vienna: Technical Report Series No. 91, IAEA.

Ma, J. Z., Ding, Z., Gates, J. B., \& Su, Y. (2007). Chloride and the environmental isotopes as the indicators of groundwater recharge in the Gobi Desert, northwest China. Journal of Environmental Geology, 55(7), 1407-1419. http://dx.doi.org/10.1007/s00254-007-1091-1

Matahelumual, B. C. (2004). Pemantauan Kondisi dan lingkungan air tanah di cekungan air tanah Bandung-Soreang Jawa Barat. Direktorat Tata Lingkungan Geologi dan Kawasan Pertambangan Bandung (Interim Report No.01/LAP/PIKPAT/2004).

Mook, W. G. (2001). Environmental isotopes in the hydrological cycle. International Hydrology Programe, 39(5). Paris: IAEA-UNESCO.

Nair, A.R., Sinha, U. K., Josep, T. B., \& Rao, S. M. (1995). Radiocarbon Dating up to 37,000 years using $\mathrm{CO}_{2}$ Absorption Technique. Nuclear Geophysics, 9(3), 263-268.

Puradimaja, D. J., \& Lubis, R. F. (2006). Hydrodynamic relationships between groundwater and river water: Cikapundung River Stream, West Java, Indonesia. IAEG2006 paper no. 488.

Qureshi, R. M., Aravena, R. O., Drimmie, R., \& Fritz, P. (1995). A simple preparatory procedure for LSC 14C dating of environmental samples with ages younger than 29,000 years. Proc. Natl. Symp. Spectroscopy for Material Analysis. Islamabad-Pakistan: April 4-6.

Ramkumar, T., Venkatramanan, S., Mary, I. A., Tamilselvi, M., \& Ramesh, G. (2010). Hydrogeochemical Quality of Goundwater in Vedaraniyam Town, TamilNadu, India. Research Journal of Environmental and Earth Sciences, 2(1), 28-44.

Wandowo, A., \& Zainal, A. D. (2002). Daerah resapan air tanah cekungan Jakarta. Pertemuan Ilmiah APISORA. Jakarta: BATAN.

Wangsaatmaja, S., Sutadian, A. D., \& Prasetiadi, M. A. N. (2005). Groundwater resources management in Bandung.Part WSustainable Groundwater Management in Asian Cities:Summary of case studies. Retrieved from http://enviroscope.iges.or.jp/modules/envirolib/upload/264/attach/part3.pdf

Wirakusumah, A. D., \& Danaryanto, H. (2004). Groundwater management in Indonesia Case Study: Groundwater conservation in Jakarta, Bandung and Semarang. 41st Coordinating Committee For Geoscience Programmes in East and Southeast Asia (CCOP) (Tsukuba, Japan).

Yatsuka, K., \& Tesuo, K. (2008). Groundwater Management Policies in Asean Mega-Cities. Library for Sustainable Urban Regeneration, 2(IV), 225-244. http://dx.doi.org/10.1007/978-4-431-78399-2_12 